\title{
Peran Perawat dalam Pengambilan Keputusan Klinis untuk Meningkatkan Keterampilan Perawat
}

\author{
Riana Silvia Casuarina L.Tobing \\ riana.sct@gmail.com
}

\section{Latar Belakang :}

Keperawatan merupakan unsur pertama dalam paradigma keperawatan, yang berarti suatu bentuk layanan kesehatan profesional. Keperawatan pada masa sekarang ini merupakan suatu seni dan ilmu yang mencakup berbagai aktivitas, konsep dan ketrampilan yang berhubungan dengan berbagai disiplin ilmu lain. Keperawatan mempunyai fungsi yang unik yaitu membantu individu, baik sehat mapun sakit, Sesuai dengan hasil kesepakatan lokakarya keperawatan nasional tentang konsep keperawatan yaitu, Keperawatan merupakan bagian integral dari layanan kesehatan yang didasarkan pada ilmu dan kiat keperawatan.Layanan ini berbentuk layananbio-psiko-sosio-spiritual komprehensif yang ditujukan bagi individu, keluarga, kelompok dan masyarakat baik sehat maupun sakit yang mencakup seluruh proses kehidupan masyarakat (Lokakarya Keperawatan Nasional,1983).Keperawatan modern merupakan suatu seni dan ilmu yang mencakup berbagai aktivitas konsep dan keterampilan yang berhubungan dengan berbagai disiplin ilmu. Keperawatan sebagai suatu profesi adalah unik karena keperawatan ditujukan ke berbagai respon individu dan keluarga terhadap masalah kesehatan yang dihadapi. Profesi keperawatan merupakan profesi yang kompleks dan beragam. Perawat berpraktik di berbagai tempat yang menuntut aspek ketrampilan dan keahlian serta disiplin yang tinggi. Keahlian dalam keperawatan merupakan hasil dari pengetahuan dan pengalaman klinik yang dijalanninya. Keahlian diperlukan untuk menginterpretasikan situasi klinik dan membuat keputusan yang kompleks dalam rangka memberikan asuhan keperawatan yang profesional dan berkualitas. Kemampuan yang sangat esensial dan berfungsi dalam semua aspek kehidupan terutama dalam melaksanakan pekerjaan diperlukan kemampuan berpikir kritis agar masalah pekerjaan dapat diselesaikan dengan baik. Menurut Halpern (1996) berpikir kritis adalah suatu upaya yang dilakukan dalam memberdayakan keterampilan atau strategi kognitif untuk 
menentukan tujuan yang diharapkan. Oleh karena itu untuk memberikan perawatan yang aman dan efektif bagi pasien dengan kebutuhan yang kompleks sangat penting bagi perawat dapat mengembangkan keterampilan berfikir kritis (Kaddoura, 2010). Kemampuan berpikir kritis perawat dibutuhkan juga dalam "transcultural nursing" yang merupakan asuhan keperawatan dengan area budaya keilmuan dalam proses pembelajaran dan praktek keperawatan focus memandang perbedaan dan kesamaannya antara budaya dengan asuhan keperawatan yang memerlukan penghargaan asuhan, sehat sakit, didasarkan pada nilai budaya manusia, kepercayaan dan tindakan, dan ilmu yang digunakan dalam melaksanakan asuhan keperawatan (Leininger, 2002).

\section{Tujuan :}

Untuk mengetahui faktor-faktor yang berhubungan dengan kemampuan berpikir kritis perawat primer dalam pelaksanaan asuhan keperawatan dan memberikan informasi dalam Peran Perawat Pengambilan Keputusan Klinis untuk Meningkatkan Keterampilan Perawat

\section{Metode :}

Jurnal ini menggunakan metode tersearch dan analisis dari berbagai sumber seperti buku teks, buku referensi jurnal, e-book, dan Thesis yang berhubungan Peran Perawat dalam Pengambilan Keputusan Klinis untuk Meningkatkan Keterampilan Perawat. Dari berbagai sumber informasi digunakan untuk mengetahui pengaruh Peran Perawat dalam Pengambilan Kepurusan Etis terhadap Keterampilan perawat dalam melakukan asuhan keperawatan. Penulisan jurnal ini dimulai pada tanggal 21 September 2020. Pengolahan jurnal dilakukan dengan metode Data diambil dengan menggunakan instrumen pernyataan faktor-faktor yang dapat mempengaruhi Pengambilan keputusan Klinis Perawat dengan tersearch dan analisis dari berabgai sumber seperti membandingkan beberapa jurnal yang berhubungan Peran Perawat dalam Pengambilan Keputusan Etis untuk Meningkatkan Keterampilan Perawat. 


\section{Hasil :}

Pengambilan keputusan dipengaruhi oleh beberapa faktor. Menurut Wlody (1990), faktor yang mempengaruhi perawat membuat keputusan adalah kebutuhan pasien, proses penyakit, hak pasien, keinginan/perasaan pasien, keinginan keluarga, tujuan yang dibuat tim pengobatan, dan faktor sosial. Berhadapan dengan dilema etik, staf perawat dan mahasiswa perawat dapat menggunakan pengambilan keputusan untuk mengatasinya. Menurut Jung\& Shannon, pengambilan keputusan etik merupakan proses rasional dan analitik karena aksi terbaik secara moral dalam situasi yang melibatkan pilihan yang berbeda ditentukan. Pembuatan keputusan etis oleh perawat perlu mengidentifikasi dan mengevaluasi pilihan tindakan serta menentukan apa yang harus dilakukan oleh perawat tersebut.

Pengambilan keputusan adalah suatu penilaian ketika fakta-fakta dapat memberikan kontribusi tetapi keputusan akhirnya harus diambil dengan menimbang-nimbang berbagai nilai atau metode untuk menjawab pertanyaan tentang dilema etik dan untuk mengorganisasi pemikiran dengan cara yang lebih logis dan sistematis.

Keputusan klinis dibuat berdasarkan antara pasien dan perawat. Oleh karena itu sebagai perawat harus meyakinkan pasien bahwa keputusan etis yang diambil berdasarkan anlisa dan pertimbangan yang matang. Kesepakatan persetujuan antara pasien dan perawat tentang keputusan tindakan tersebut dapat berupa informed consent sehingga terdapat bukti yang kuat bahwa keputusan tersebut diambil berdasarkan keperawatan bersama. Dalam setiap pengambilan keputusan oleh peran perawat adalah sebagai konselor dan advokat. Artinya perawat harus memberikan informasi tentang kondisi dan situasi yang terjadi, dan melibatkan pasien dan keluarga dalam proses pengambilan keputusan dan melindungi hak pasien untuk mendapatkan perawatan yang menguntungkan dan tidak merugikan 


\section{Pembahasan :}

Perawat merupakan tenaga profesional yang bertanggung jawab dalam memberikan proses keperawatan kepada klien. Berdasarkan hal tersebut perawat harus mampu mengambil keputusan klinis sebagai upaya membantu pasien dalam memecahkan masalah dan menemukan jalan keluar dari setiap masalah keperawatan yang dialami pasien. Perawat selalu dihadapkan dengan berbagai masalah klinis dalam memberikan perawatan terhadap pasien. Perawat yang profesional tentu saja akan mampu mengambil keputusan agar masalah pasien dapat diatasi dengan cepat dan tepat. Kurangnya kemampuan perawat dalam mengambil keputusan dalam situasi yang kris tentu saja akan membahayakan pasien dan menimbulkan kerugian bagi pasien, diantaranya pasien akan terlambat untuk mendapatkan bantuan hidup, kondisi pasien akan semakin memburuk dan akibat yang paling fatal adalah kemaan (Poer \& Perry, 2009).

Faktor-faktor yang bisa menyebabkan perbedaan dalam mengukur berpikir kritis antara hasil seseorang yang satu dengan yang lainnya menurut American Society of Registered Nurses (2007) adalah dijelaskan berpikir kritis dalam keperawatan sangat dipengaruhi oleh karakter psikologis, fisiologis, serta dapat dipengaruhi oleh lingkungan internal maupun eksternal seperti usia, tingkat kepercayaan, keterampilan, stress, dan kelelahan, serta rekan kerja. Sedangkan hasil penelitian lainnya dikatakan bahwa kemampuan berpikir kritis perawat dalam melaksanakan proses keperawatan tidak dipengaruhi oleh karakteristik individu seperti umur, jenis kelamin, pendidikan, dan pengalaman kerja serta status perkawinan (Sumartini, 2010). Sedangkan dijelaskan oleh lainnya bahwa factor salah satunya yang bisa menurunkan kemampuan berpikir kritis seseorang adalah terjebak dalam rutinitas, dan juga cara tersering yang membuat terjebak dalam rutinitas adalah membiasakan kita menggunakan model kebiasaan berlebihan (Rubenfeld \& Scheffer, 2007). Faktor-faktor lainnya yang dapat juga mempengaruhi kemampuan seseorang dalam berpikir kritis adalah kondisi fisik seseorang, keyakinan diri/ motivasi, merasa kecemasan, kebiasaan atau rutinitas yang dikerjakan, perkembangan intelektual, konsistensi atau ketetapan, perasaan atau emosi, dan pengalaman yang biasa rutin dilakukan sewaktu bekerja (Rubenfeld \& 
Scheffer, 2007; Maryam, Setiawati, \& Ekasari, 2007). Berbagai faktor tersebut dapat berkontribusi memberikan pengaruhnya terhadap kemampuan berpikir kritis perawat disaat melaksanakan asuhan keperawatan dan juga dapat mempengaruhi kemampuan berpikir kritis perawat menurun disaat menghadapi pasien. Namun ini juga tergantung dari metode yang digunakan dalam mengukur kemampuan berpikir kritis perawat disaat melaksanakan asuhan keperawatan. Survey yang dilaksanakan di rumah sakit masih ditemukan perawat dalam melaksanakan asuhan keperawatan hanya sebatas rutinitas kebiasaan yang belum mengembangkan keterampilan berpikir kritis. Hasil observasi dokumentasi asuhan keperawatan sebagai pencatatan pada critikal thingking dalam melaksanakan asuhan keperawatan mulai dari pengkajian sampai dengan evaluasi belum tergambar secara lengkap. Padahal rumah sakit telah mengembangkan sumber daya manusianya melalui pelatihan - pelatihan pengembangan ilmu keperawatan salah satunya adalah komunikasi therapeutik dalam keperawatan, penerapan keterampilan berpikir kritis bagi perawat dalam melaksanakan asuhan keperawatan.

Proses dalam pengambilan keputusan dipengaruhi oleh dua faktor, yaitu kontekstual dan individual. Faktor kontekstual meliputi kesadaran moral, sedangkan faktor individual dipengaruhi oleh nilai keyakinan, pengalaman, pengetahuan dan juga keterampilan. Faktor pasien juga berpengaruhi dalam proses pengambilan keputusan etik. Perawat sering dihadapkan dengan dilema etik pada saat pengambilan keputusan. Perawat harus terbiasa dengan proses pengambilan keputusan etik saat memberikan asuhan (Ebrahimi et al., 2015). Pengambilan keputusan dipengaruhi oleh dokter penanggung jawab, diagnosa dan usia pasien. Dalam memberikan pelayanan kesehatan dokter dengan perawat terkadang memiliki pendapat yang berbeda mengenai perawatan pasien atau pengambilan keputusan yang tepat pada pasien. Dokter memutuskan untuk melakukan perawatan lebih lanjut, tetapi perawat menilai bahwa perawatan harus dihentikan. Namun, terkadang menurut perawat perawatan pasien dilanjutkan tapi dokter penanggung jawab pasien memutuskan untuk menghentikan pengobatan(Silen et al., 2008). Beberapa penelitian (Bucknall\& Thomas; Ferrand et al., 2003, Manias, 1998; Rocker et al., 2005) telah menggambarkan dalam 
proses pengambilan keputusan bila dokter tidak melibatkan perawat dalam pengambilan keputusan mengenai pengobatan maka hasilnya kurang baik, sedang apabila perawat dilibatkan maka hasilnya baik. Sementara itu, Wilson dkk. dalam penelitiannya tentang pemahaman otonomi terkait perawatan pasien akhir hidup (paliatif) mengemukakan bahwa pengambilan keputusan berpusat pada pasien yang telah diidentifikasi perawatan paliatif. Wilson juga menyimpulkan bahwa pada pasien paliatif dalam menggunakan model ekologi dalam proses pengambilan keputusan dalam pemberian pelayanan kesehatan kepada pasien. Mengakui otonomi dalam pengambilan keputusan itu sangat berarti terhadap perawatan profesional kepada pasien. Model ini juga mendukung otonomi bukan hanya pada saat pengambilan keputusan tetapi juga dapat diterapkan pada saat melakukan asuhan keperawatan sehari hari (Wilson, Ingleton, Gott \& Gardiner, 2014).

\section{BERFIKIR KRITIS DALAM PROSES KEPERAWATAN}

\section{A. Pengkajian}

\section{a. Pengkajian}

Pengkajian adalah upaya mengumpulkan data secara lengkap dan sistematis untuk dikaji dan dianalisis sehingga masalah kesehatan dan keperawatan yang di hadapi pasien baik fisik, mental, sosial maupun spiritual dapat ditentukan tahap ini mencakup tiga kegiatan,yaitu Pengumpulan Data, Analisis Data dan Penentuan Masalah kesehatan serta keperawatan.

\section{Pengumpulan data}

Diperoleh data dan informasi mengenai masalah kesehatan yang ada pada pasien sehingga dapat ditentukan tindakan yang harus diambil untuk mengatasi masalah tersebut yang menyangkut aspek fisik, mental, sosial dan spiritual serta faktor lingkungan yang mempengaruhinya. Data tersebut harus akurat dan mudah dianalisis. Jenis data antara lain:

a) Data Objektif, yaitu data yang diperoleh melalui suatu pengukuran, pemeriksaan, dan pengamatan, misalnya suhu tubuh, tekanan darah, serta warna kulit. 
b) Data subjekif, yaitu data yang diperoleh dari keluhan yang dirasakan pasien, atau dari keluarga pasien/saksi lain misalnya; kepala pusing, nyeri dan mual. Adapun fokus dalam pengumpulan data meliputi :

1) Status kesehatan sebelumnya dan sekarang

2) Pola koping sebelumnya dan sekarang

3) Fungsi status sebelumnya dan sekarang

4) Respon terhadap terapi medis dan tindakan keperawatan

5) Hal-hal yang menjadi dorongan atau kekuatan klien

2. Analisa data adalah kemampuan dalam mengembangkan kemampuan berpikir rasional sesuai dengan latar belakang ilmu pengetahuan. Perumusan masalah Setelah analisa data dilakukan, dapat dirumuskan beberapa masalah kesehatan. Masalah kesehatan tersebut ada yang dapat diintervensi dengan Asuhan Keperawatan (Masalah Keperawatan) tetapi ada juga yang tidak dan lebih memerlukan tindakan medis. Selanjutnya disusun Diagnosis Keperawatan sesuai dengan prioritas. Prioritas masalah ditentukan berdasarkan kriteria penting dan segera. Penting mencakup kegawatan dan apabila tidak diatasi akan menimbulkan komplikasi, sedangkan Segera mencakup waktu misalnya pada pasien stroke yang tidak sadar maka tindakan harus segera dilakukan untuk mencegah komplikasi yang lebih parah atau kematian. Prioritas masalah juga dapat ditentukan berdasarkan hierarki kebutuhan menurut Maslow, yaitu : Keadaan yang mengancam kehidupan, keadaan yang mengancam kesehatan, persepsi tentang kesehatan dan keperawatan.

\section{B. Diagnosa Keperawatan}

Diagnosa Keperawatan adalah suatu pernyataan yang menjelaskan respon manusia (status kesehatan atau resiko perubahan pola) dari individu atau kelompok dimana perawat secara akuntabilitas dapat mengidentifikasi dan memberikan intervensi secara pasti untuk menjaga status kesehatan menurunkan, membatasi, mencegah dan merubah (Carpenito, 2000). 
Perumusan diagnosa keperawatan :

1) Actual : Menjelaskan masalah nyata saat ini sesuai dengan data klinik yang ditemukan.

2) Resiko : Menjelaskan masalah kesehatan nyata akan terjadi jika tidak dilakukan intervensi.

3) Kemungkinan : Menjelaskan bahwa perlu adanya data tambahan untuk memastikan masalah keperawatan kemungkinan.

4) Wellness : Keputusan klinik tentang keadaan individu, keluarga atau masyarakat dalam transisi dari tingkat sejahtera tertentu ketingkat sejahtera yang lebih tinggi.

5) Syndrom : diagnose yang terdiri dar kelompok diagnose keperawatan actual dan resiko tinggi yang diperkirakan muncul/timbul karena suatu kejadian atau situasi tertentu.

\section{Rencana keperawatan}

Rencana asuhan keperawatan yang di rumuskan dengan tepat memfasilitasi konyinuitas asuhan perawatan dari satu perawat ke perawat lainnya. Sebagai hasil, semua perawat mempunyai kesempatan untuk memberikan asuhan yang berkualitas tinggi dan konsisten. Rencana asuhan keperawatan tertulis mengatur pertukaran informasi oleh perawat dalam laporan pertukaran dinas. Rencana perawatan tertulis juga mencakup kebutuhan klien jangka panjang(potter,1997)

\section{Implementasi keperawatan}

Merupakan inisiatif dari rencana tindakan untuk mencapai tujuan yang spesifik. Tahap pelaksanaan dimulai dimulai setelah rencana tindakan disusun dan ditujukan pada nursing orders untuk membantu klien mencapai tujuan yang diharapkan. Oleh karena itu rencana tindakan yang spesifik dilaksanakan untuk memodifikasi faktor-faktor yang mempengaruhi masalah kesehatan klien.

Adapun tahap-tahap dalam tindakan keperawatan adalah sebagai berikut :

1) Tahap 1 : persiapan Tahap awal tindakan keperawatan ini menuntut perawat untuk mengevaluasi yang diindentifikasi pada tahap perencanaan.

2) Tahap 2 : intervensi Focus tahap pelaksanaan tindakan perawatan adalah kegiatan dan pelaksanaan tindakan dari perencanaan untuk memenuhi 
kebutuhan fisik dan emosional. Pendekatan tindakan keperawatan meliputi tindakan : independen,dependen,dan interdependen.

3) Tahap 3 : dokumentasi Pelaksanaan tindakan keperawatan harus diikuti oleh pencatatan yang lengkap dan akurat terhadap suatu kejadian dalam proses keperawatan.

\section{E. Evaluasi Perencanaan}

Evaluasi memuat criteria keberhasilan proses dan keberhasilan tindakan keperawatan. Keberhasilan proses dapat dilihat dengan jalan membandingkan antara proses dengan pedoman/rencana proses tersebut. Sedangkan keberhasilan tindakan dapat dilihat dengan membandingkan antara tingkat kemandirian pasien dalam kehidupan sehari-hari dan tingkat kemajuan kesehatan pasien dengan tujuan yang telah di rumuskan sebelumnya.

Sasaran evaluasi adalah sebagai berikut:

1) Proses asuhan keperawatan, berdasarkan kriteria/ rencana yang telah disusun.

2) Tujuan tidak tercapai,apabila pasien tidak menunjukan perubahan/kemajuan sama sekali bahkan timbul masalah baru.dalam hal ini perawat perlu untuk mengkaji secara lebih mendalam apakah terdapat data, analisis, diagnosa, tindakan, dan faktor-faktor lain yang tidak sesuai yang menjadi penyebab tidak tercapainya tujuan.

Hasil tindakan keperawatan ,berdasarkan kriteria keberhasilan yang telah di rumuskan dalam rencana evaluasi. 


\section{PENUTUP :}

Ketepatan pengambilan keputusan akan di pengaruhi oleh kompentisi perawat, kemampuan berkomunikasi, lingkungan serta budaya. Penting bagi perawat untuk selalu meningkatkan kapasitas dirinya dalam pemberian asuhan keperawatan hal ini akan meningkatkan kepercayaan masyarakat terhadap perawat yang selanjutnya akan meningkatkan profesionalisme perawat. Hal ini bisa digunakan sebagai acuan dalam melakukan hubungan interdisiplin Pengambilan keputusan yang tepat akan meningkatkan kemandian klien dalam asuhannya serta membantu klien untu menentukan pilihan bantuan yang tepat sesuai dengan kondisinya. Klien yang mandiri akan menurunkan beban kerja perawat sehingga pelayanan keperawatan akan lebih efektif dan efisien dalam penggunaan sumber daya. Untuk itu dibutuhkan banyak dukungan dalam implementasi shared clinical decision making ini, missal dibuatkannya SPO pengambilan keputusan klinis keperawatan, meningkatkan sumber daya perawat dengan menciptakan perawat yang caring perawat yang peka budaya perawat memperhatikan etik, disiplin danbioteik keperawatn dalam setiap asuhahhnya sebagai upaya untuk meningkatkan kemampuan berkomunikasi memberikan dukungan kepada pasien, sehingga dubutuhkan PKB (Pendidikan Keperawatan Berkelanjutan) atau dengan sistem preseptorship untuk membentuk perawat yang kompeten, mempunyai kemampuan critical thinking dalam pengambilan keputusan klinis keperawatan. Organisasi profesi mempunyai peranan yang penting dalam mewujudkan perawat yang kompeten dalam melakukan pengambilan keputusan klinis keperawatan.

Mutu asuhan keperawatan menjadi alat utama menjaga kepercayaan pelayanan. Asuhan keperawatan bermutu dilakukan dengan meningkatkan kemampuan berpikir kritis perawat dalam melakukan proses keperawatan. Pelayanan keperawatan didasarkan pada pendekatan pengambilan keputusan yang dapat ditingkatkan dengan berpikir kritis. Berpikir kritis dalam keperawatan merupakan keterampilan berpikir perawat menguji berbagai alasan secara rasional sebelum mengambil keputusan dalam asuhan keperawatan.Berpikir kritis dalam asuhan keperawatan memberikan jaminan keamanan dan memenuhi standar pelayanan. Berpikir kritis merupakan suatu pengujian yang rasional terhadap beberapa ide, kesimpulan, prinsip, argumen, penjelasan, persoalan, pernyataan, keyakinan dan 
tindakan, serta inti dari praktik keperawatan profesional (Taylor, 2006). Berpikir menjadi bagian tak terpisahkan dari asuhan keperawatan yang dilakukan oleh perawat. Berpikir kritis penting dilakukan oleh perawat sebelum mengambil keputusan dalam asuhan keperawatan.Asuhan keperawatan merupakan satu metode ilmiah dalam penyelesaian masalah klien. Kemampuan perawat mengidentifikasi masalah klien dan memilih solusi intervensi yang tepat tidak lepas dari kemampuan perawat berpikir kritis, yaitu kemampuan perawat menggali alasan berdasarkan evidence base dari setiap permasalahan dan solusi yang teridentifikasi. Kemampuan berpikir kritis dan disposisinya dapat digunakan ketika menyelesaikan masalah keperawatan. 


\section{DAFTAR PUSTAKA}

Ali, S. (2019). Pengaruh Pelatihan Etik Keperawatan Terhadap Penguatan Peran Perawat Dalam Pengambilan Keputusa Etik Di Rumah Sakit Umum Swasta Kota Medan, Tesis F.Kep USU.

Arisudhana, B. A. , Anggayani, N. M. \& Kadiwanu, O. C. (2019). Kemampuan Penelaan Klinis Mahasiswa Perawat Tahun Keempat Pada Masalah Keperawatan Medikal Bedah. Jurnal Caring 3(1),58-62.

Khairina, I. , Malini, H. , Huriani, E. (2020). Pengetahuan dan Keterampilan Klinis Perawat Dalam Pengambilan Keputusan Klinis Triase. Jurnal LINK, 16(1), $1-5$.

Kemenkes RI (2016). Modul Bahan Ajar Cetak Keperawatan. Konsep Dasar Keperawatan. Jakarta : Depkes RI.

Kurniadi, A. (2013). Manajemen Keperawatan dan Prospektifnya: Teori, Konsep dan Aplikasi. Jakarta : FK UI.

Kowiyah. (2012). Kemampuan Berikir Kritis. Jurnal Pendidikan Dasar, 3(5), 1922

Lutfiani, D.L. Achamadi, dkk. (2015). Gambaran Tingkat Pengetahuan Dalam Penerapan Standart Asuhan Keperawatan Di Ruangan Rawat Inap Interna RSUD Datoe Bhimamgkang. Jurnal Keperawatan ,3(3).

Mulyaningsih. (2013). Peningkatan perilaku caring melalui kemampuan berpikir kritis perawat. Jurnal Manajemen Keperawatan, 1 (2), 100-106.

Simamora, R. H. (2019). Menjadi perawat yang: CIH'HUY. Surakarta: Kekata Publisher.

Simamora, R. H. (2005). Hubungan Persepsi Perawat Pelaksana Terhadap Penerapan Fungsi Pengorganisasian Yang Dilakukan Oleh Kepala Ruangan Dengan Kinerjanya Diruang Rawat Inap RSUD Koja Jakarta Utara (Doctoral dissertation, Tesis FIK UI, Tidak dipublikasikan). 
Sutriyanti, Y. , \& Mulyadi (2019). Analisa Faktor - Faktor yang Mempengaruhi Penerapan Berpikir Kritis Perawat Dalam Melaksanankan Asuhan Keperawatan DI Rumah Sakit. Jurnal Keperawatan Raflesia 1(1), 22-32

Sudono, dkk. (2017). Gambaran Kemampuan Berpikir Kritis Perawat Primer Dalam Pelaksanaan Asuhan Keperawatan Di Rumah Sakit Islam Surakarta. Jurnal Ilmu Keperawatan Indonesia 10(1), 81-84 